\title{
DETERMINANTS OF LOAN REPAYMENT BY BENEFICIARY FARMERS UNDER THE INTEGRATED FARMERS SCHEME IN AKWA IBOM STATE OF NIGERIA
}

\author{
R. O. Mejeha, A. E. Bassey and I. O. Obasi \\ Department of Agricultural Economics, Michael Okpara University Umudike, Abia State, Nigeria
}

\begin{abstract}
This study examined determinants of loan repayment by beneficiary farmers under the Integrated Farmers Scheme (IFS) in Akwalbom State of Nigeria. Most government and other institutional funding effort to agricultural sector have been fraught with difficulties especially defaulting on loan contract. The specific objectives are: assess the factors that affect loan repayment among the beneficiaries, examine the level of loan repayment performance and to ascertain the factors that influence loan repayment of the beneficiaries in the study area.Primary data used for the study were collected with the aid of a well-structured questionnaire. Simple random sampling was used to select the eighty four respondents. Data collected were analyzed using mean, percentages and Ordinary Least Square. Result shows that $89.23 \%$ of beneficiaries indulged in diversion of loan to family uses. Loan performance indices estimated shows that only $25.94 \%$ of borrowed amount was repaid as at when due. This situation indicated a low repayment performance. Empirical result shows that loan from other sources, farming experience, amount of money borrowed and total income were the significant factors that influenced loan repayment. It was concluded that low repayment limited effective loan administration in the study area. It was recommended that regular monitoring by lender should be heightened to ensure prompt repayment. Farmers should be encouraged by the funding agency to repay loan promptly, this could be through education, persuasion and at times necessary threatening with Police arrest and exclusion from further funding.
\end{abstract}

Keywords: Loan Repayment, Farmer Beneficiary, Integrated Farmers Scheme, Determinants.

https://dx.doi.org/10.4314/jafs.v16i2.7

\section{INTRODUCTION}

Loan is an amount of money or any scarce resource lent by a lender to borrower(s) to enable him/her enjoy some goods and services now with the hope of paying in the future with some interest Agricultural and Rural Management Training Institute (ARMTI, 2016). Emphasis on availability of debt capital to farmers had become imperative, because given the amount of money required to operate a farm commercially, most farmers lack adequate equity capital to invest in agriculture, hence necessitating the institutional agencies to avail the farmers the required capital base through credit. Over the years, credit has been an important policy instrument that can facilitate the application of modern technologies and increase in farm production. This is obvious because most innovations in agriculture inevitably increase the capital requirement of farmers (Okpara et al., 2013; Hosseini et al., 2012; Okwara et al., 2016; Mejeha and Obundike 1998). In recent times, various levels of government had emphasized the need to wade into the most talked 
about problem of agriculture by providing the finance needed by farmers through credit. However, the basis of this provision of finance to farmers by government supported credit programs lies theoretically on the belief that, the availability of credit increases farm income and farmers welfare, and can equally shield the farmers from the exploitative tendencies of the informal credit providers. Credit is basic to poverty reduction, livelihood diversification and increases the business skills of small holder farmers (Ololade and Olagunju, 2013). Credit is not only a tool to increase farm productivity and income; but also plays a function in fulfilling the social function by improving the lives of the rural people (Musugi, 2002); Nwaru, et al., 2011). Credit could achieve all these especially under ideal socio-economic and environmental situations such as age of farmers and tittle held in the community religion, social attitudes and values, familiarity with credit agencies, concessional interest rate, complementary inputs and services offered by lenders of fund, good farm management practices, return on investment, type of farming, marketing facilities, good roads, electricity, good water supply and good healthcare facilities.

In Akwa Ibom State, the Integrated Farmers Scheme (IFS) was established by the State Government as a deliberate intervention strategy in financing agriculture in the State on commercial and sustainable basis. The Integrated Farmers Scheme was established in 1998 under the Akwa Ibom State Ministry of Agriculture and managed as a project under the State micro-credits scheme. The Bill establishing the scheme was passed into law in 2003. Integrated Farmers Scheme (IFS) has been functional till date; the scheme covers food crop production such as plantain, pineapple and livestock farming enterprises such as poultry, piggery and aquaculture. In piggery production enterprise for instance, the loan period is about four and half years at ten percent rate of interest with a moratorium of one year. At present the loan size is fixed at five hundred thousand naira only, secured by guarantee/surety for any agricultural enterprise in the scheme (Anuku and Ebong, 2011).

An important aspect of Integrated Farmers Scheme is training of the prospective beneficiaries before granting loan to them. The Integrated Farmers Scheme (IFS) has been established out of the desire and effort to exploit the vast untapped agricultural potentials of the state with the following objectives: granting of loan to prospective beneficiaries, training and empowerment of farmers, increasing the farm work-force by introducing the energetic youths to take up farming and replace the aging parents and used the improved technology; reducing unemployment thereby curbing youth restiveness with it attendant vices; promoting and dignifying farming as a viable business venture thus stimulating the youth male and female to take to agriculture; increasing food production and income levels of the State.

When loans are disbursed, the key issues of utilizing the loan on the intended purpose and repayment comes up. Loan repayment is the capacity and propensity of the farmers to meet lending obligation as agreed on the loan contract arrangement. Repayment of borrowed agricultural funds has been one of the recurring themes of agricultural development in the developing economies such as Nigeria (Nwachukwu et al., 2010). Lending Institutions would grant loan to intending beneficiaries on the expectations of full recovery, but the finite number of potential beneficiaries seeking credit from a credit market has different propensities of either repaying or otherwise regardless of the credit contract. Most often, the expectation of lenders for full repayment of loan fails. When this happens, the level of loan repayment made by a beneficiary as defined by a loan repayment index (LRI) is low while the loan default index (LDI) which defines the level of default by a beneficiary become otherwise. Loan repayment is an imperative for the survival of financial institutions (Ndiege et al., 2016). Low repayment of loan is widely reported in literature especially 
small holder farmers in developing economies. In Nigeria, several researchers (Udoh, 2008) reported a low repayment of about 25\% among beneficiaries of Akwa Ibom State Agricultural Loan Board (AKSALB). Acqnah and Addo (2011), reported a repayment rate of 29.1\% in the study on fishermen in Ghana, Onyenucheya and Ukoha 2007 reported repayment rate of $45 \%$ in their study on farmers under the Agricultural Cooperative and Rural Development Bank (now Bank of Agriculture) in Abia State, Nigeria.

In Akwa Ibom State, the rate at which the borrower repay his loan which is defined as borrower repayment rate (BRR) has been the major problem faced by the scheme. This condition tends to create hitch on long term viability and availability of funds for lending to new borrowers who are in good standing. This is because no lending scheme can sustainably operate a revolving loan without the borrowers properly fulfilling their loan repayment obligation. Defaulting on loan contract is quite widespread especially among borrowers who perceived government sponsored loans more as grant than debt that has to be repaid (Poulton et al., 1998). The issue of low repayment therefore makes the policy of the government aimed at establishing institutional credit markets as prospective credit sources of loanable funds to farmers to be highly impaired. This study examines the determinants of loan repayment among beneficiaries under IFS in AKS.The specific objectives are: assess the factors including (institutional) that affect loan repayment among the beneficiaries, examine level of loan repayment performance and ascertain the factors that influence loan repayment of the beneficiaries in the study area.

\section{MATERIALS AND METHODS}

The study area: The study was carried out in Akwa Ibom State. It is one of the thirty six states in Nigeria with Uyo as the State capital. Akwa Ibom State is located in the South-East ecological zone between Latitude $4^{0} 33^{\prime}$ and $5^{0} 35^{\prime}$ North and Longitudes $7^{0} 35^{\prime}$ and $8^{0} 35^{\prime}$ East. Its covers a total land area of 8,412 kilometers square. The State is bounded by Abia state in the North, Rivers State in the West, Cross River State in the East and the Atlantic Ocean in the South. The State falls within the humid tropics with two distinctive seasons namely, rainy season (May to October) and dry season (November to April). Annual mean rainfall ranges between $2000 \mathrm{~mm}$ and $2400 \mathrm{~mm}$ along the coast. Mean daily maximum temperatures are regular about $26^{\circ} \mathrm{C}-33^{\circ} \mathrm{C}$ and the relative humidity is between $50 \%$ to $60 \%$ during the dry season and between $60 \%$ and $90 \%$ in the rainy season. With the population of about 3,920,208 people (NPC, 2006). Over $70 \%$ are involved in agriculture for both subsistence and income generation.

Sampling procedure: The study was carried out in all the three operational zones of the scheme namely Uyo, Eket and Ikot Ekpene. This was to ensure that all the operative base of the scheme is covered. The population of the study consisted of male and female farmers who benefitted from the medium term loan granted by the scheme that lasted between (2011-2015) and who had at least completed a cycle of farm production.

Sample size and data collection.A list of loan beneficiaries who collected loan from IFS between (2011-2015) was obtained from the accounts department. From the list of loan beneficiaries, a simple random sampling technique was used to select 84 loan beneficiaries that participated in this study. The data used in this study include both primary and secondary data. The secondary data were collected from the official records of the Akwa Ibom State Integrated Farmers Scheme (IFS). The primary data were collected with the aid of structured questionnaire, which was administered to 
selected IFS loan beneficiaries who were granted a medium term loan that lasted for five years (2011-2015).

Data Analysis: Loan repayment performance of the beneficiaries was achieved by evaluation of two indices. These include loan repayment index and borrower repayment rate. Loan Repayment Index: This is evaluated as follows:

$\mathrm{LRI}=\left[\mathrm{BVR} \mathrm{f}_{\mathrm{f}} / \mathrm{VB}+\mathrm{W}_{2}(\mathrm{BVRp} / \mathrm{VB})\right]^{*} 100$-------- (1).

This model had been used by Udoh (2008); Etukumoh and Akpaeti (2015) to measure loan repayment performance. Where LRI is loan repayment index, which shows the level of repayment made by a beneficiary; $\mathrm{W}_{2}=\mathrm{NRCp} / \mathrm{TNLOp} ; \mathrm{BVR}_{\mathrm{f}}=$ value of loan paid by those who made full repayment; $\mathrm{VB}=$ total value of loans outstanding in period under review; $\mathrm{BVRp}=$ value of loans paid by those who made partial repayment; NRCp = number of borrowers who made partial repayment; TNLOp = total number of borrowers who have outstanding loan to repay.

Loan default index is thus measured as follows:

$\mathrm{LDI}=100-\mathrm{LRI}$

Where: LDI= Loan Default Index; LRI= Loan Repayment Index

\section{Borrower Repayment Rate:}

This is given as: $\mathrm{BRR}=\left[\mathrm{BNF}_{\mathrm{f}} / \mathrm{NB}+\mathrm{W}_{1}(\mathrm{BNRp} / \mathrm{NB})\right]^{*} 100$

Where BRR is the borrowers' repayment rate, which is defined as the rate at which the borrowers repay or fulfill their loan obligation; $\mathrm{W}_{1}=\mathrm{VRCp} / \mathrm{TVLOp} ; \mathrm{BNF}_{\mathrm{f}}=$ number of borrowers who made full repayment; $\mathrm{NB}=$ total numbers of beneficiaries in a particular period; $\mathrm{BNRp}=$ numbers of borrowers who made partial repayment; $\mathrm{VRCp}=$ value of repayment collected from those who made partial repayment; TVLOp = total value of loans outstanding for those who made partial repayment.

Borrowers' default index is then measured as follows:

$\mathrm{BDR}=100-\mathrm{BRR}$

Where BDR is Borrowers' Default Ratio and BRR is Borrower Repayment Rate

Multiple regression analysis was used to ascertain the factors that influence loan repayment among the beneficiaries of Integrated Farmers Scheme.

The multiple regression model is implicitly stated as;

$\mathrm{Y}=\mathrm{f}\left(\mathrm{X}_{1}, \mathrm{X}_{2}, \mathrm{X}_{3}, \mathrm{X}_{3}, \mathrm{X}_{4}------\mathrm{X}_{9}\right)$

Where:

$\mathrm{Y}=$ Amount of loan repaid (in naira); $\mathrm{X}_{1}=$ Age of farmer (in years)

$\mathrm{X}_{2}=\operatorname{Sex}($ male $=1$; female $=0) ; \mathrm{X}_{3}=$ Level of education (in years)

$\mathrm{X}_{4}=$ Farming experience (in years); $\mathrm{X}_{5}=$ enterprise type ( $\mathrm{crop}=1$; livestock $=0$ )

$\mathrm{X}_{6}=$ Total income of the farmer (Naira); $\mathrm{X}_{7}=$ Amount of loan obtained (Naira) 
$\mathrm{X}_{8}=$ loan from other sources (Naira); $\mathrm{X}_{9=}$ Interest amount (Naira)

\section{RESULTS AND DISCUSSION}

The factors that affect loan repayment among Integrated Farmers Scheme beneficiaries: The result of the factors that affected loan repayment is shown in Table 1. The result shows that $70.23 \%$ of the beneficiaries could not repay their loan promptly owing to the fact that their loans were approved late. Late approval of loans may be due to the fact that all processes on loan have to be duly completed before approval and often time takes longer time. Affected farmer may be granted loan after the planting season had commenced. This eventually could cause the loan to end up as additional consumption instead on agricultural production, hence a repayment problem Nwaru, (2011). Incorrect credit appraisal was recognized by both beneficiaries and institution. When loan officers do not see the need or have the ability to review feasibility reports or farmers claim of scale of operation before loan approval, this will enhance approval of loan to unviable project, hence impact loan repayment negatively. This is obvious because, farmers often time make exaggerated assessment of their credit needs during application. This factor was accounted for by $23.81 \%$ of the beneficiaries.

Diversion of loan to family use was a factor with highest frequency, and affected $89.23 \%$ of the beneficiaries in repaying their loan promptly. When farmers use loan money for things other than the productive purpose which it was granted, it will reduce the management ability of the farmer as he could not buy new technologies and inputs. This result in lower income, hence repayment problem. Under financing where inadequate amount of money is release for a project was accounted for by $21.43 \%$ of beneficiaries to be the reason they could not repay their loan promptly. Finance has been regarded as the greatest limiting factor to the advancement of agriculture in Nigeria (ANAN, 2017). The central Bank of Nigeria has observed that inadequate funds are supplied to agricultural sector (CBN, 2010;Elum, 2017). This could largely depend on the forces of demand and supply of loanable fund that influenced the financial markets. Consequently banks rely on loan rationing for eligible beneficiaries. Inadequate fund enhances underutilization of other factors of production hence repayment problem resulting from low income. Poor monitoring by credit officers often time affect project implementation hence a repayment of loan. This has been accounted for by $70.23 \%$ of the beneficiaries. This is especially true when the beneficiaries have not been reminded or disturbed by the officers for repayment (Ayanda and Ogunsekan, 2012)

Production losses affected $71.43 \%$ of the beneficiaries in fulfilling their loan obligation promptly. Sources of production losses in the farm include excessive rainfall, erosion, flood, pest and diseases, fire outbreak, thefts and pilfering, straying animals environmental pollution and incorrect use of agro chemicals ARMTI, 2016. These losses when translated into monetary value may be large enough to reduce net profit hence, repayment ability. Low prices of produce affected $47.62 \%$ of the beneficiaries. At the peak of the harvest, farm produce markets are always characterized by excess supply of farm produce which eventually drag down prices and result in low income hence repayment problem to the beneficiaries of loan. Lack of business knowledge/cost of production and high interest rate charged were factors accounted for by $40.47 \%$ and $53.57 \%$ respectively. Most people are in farming business to make as much profit as possible in the shortest possible time using the available resources. However, the achievement of this objective depends to a large extent on cost minimization. Often time, farmers fail in planning and organizing their farm more 
profitably, thus reducing beneficiary's ability to repay loan. The incidence of moral hazard where beneficiaries deliberately refuse to repay their loans even when they have the capacity to do so was a factor for low repayment and accounted for by $80.95 \%$ of the beneficiaries.

Level of loan repayment performance: the summary of loan repayment statistics of the beneficiaries is shown in Table 2.According to the Table, majority of the beneficiaries (78.57\%) were those who repaid their loan partially, they also made the highest amount of repayment of $55.50 \%$. Borrowers who repaid outside the stipulated time frame were considered as defaulters because they did not repay their loans on time. Beneficiaries who repaid their loans untimely are not very jealous of their credit reputation. Because of this, they are negligent in honouring their contractual obligations promptly as and when due. The reasons beneficiaries repaid their loan partially can be linked to diversion of loan for family use and unwillingness to repay, this is because, human nature is such that given the opportunity they would like to delay repayment of debt. However, untimely repayment of loan discourage financial institutions to continue on their role of lending credit to farmers sustainably, this is because prompt repayment of loan is an imperative for the survival of financial institutions, recycling of public fund for development and building up confidence among the credit institutions in their clients on their ability to develop (Ndiege et al., 2016; Rathore et al., 2017).To fully measure the level of loan repayment, loan performance indices were estimated and presented on Table 3. The result shows a low level of repayment among the benefitting farmers across the entire enterprises of the scheme. Specifically, about $25.94 \%$ of loan granted to IFS beneficiaries were only repaid when due.

\section{Factors that affect loan repayment of the beneficiaries}

The result of the factors that affect loan repayment among IFS beneficiaries were ascertained using multiple regression analysis. The linear function was chosen as the lead equation because it had the best fit. The regression line gave a coefficient of multiple determinations $\left(\mathrm{R}^{2}\right)$ of $85.81 \%$. This implies that, the four explanatory variables explained $85.81 \%$ of the variation in the independent variable. The result of the factors of loan repayment for IFS beneficiaries is presented in Table 4.The significant variables include sex, loan from other sources, amount of money borrowed and total income.Sex of the beneficiaries was found to be directly related to the amount of loan repaid and significant at 5\% level of confidence. The direct relationship with the amount of loan repaid implies that male farmers had increased tendency to repay borrowed money more than their female counterparts. These higher tendencies for male to repay could be explained by the fact that, male farmers have greater access to family resources such as land as is typical of the study area, a situation which the male farmers utilized to increase income when they put such resource into production. This eventually reduces production cost and increases total and enhances their ability to repay their loan positively. This result is contrary to the findings of Udoh (2008); Abu et al (2016); Abu et al (2017) who found out that male beneficiaries of loan had higher tendencies to default than female farmers.

Loan obtained from other sources contributed positively to loan repayment and significant at 5\% level of confidence. The statistical significance and the sign of the estimated coefficient being positive clearly show that loan repayment will increase for the beneficiaries with multiple loan sources. This implies that, farmers who had access to more than one credit stock will perform better in repayment. This could be explained by the fact that, since Agricultural sector has been underfinanced (Global Agricultural Information Network, 2011), farmers can mostly get adequate finance for their operation through multiple borrowing. This is because one source of financing 
could hardly meet their requirement for investment. Farmers can easily borrow from informal associations that operate traditional microfinance in rural communities because most of them are members and stakeholders (Mejeha and Echebiri, 2006). Loans obtained from informal sources could be used in establishment of enterprises while waiting for the institutional loan which often time could be delayed, this process enable farm production to commence on time hence, enhancing better output and loan repayment. This result is in line with Aryeetey (1995) who examined the determinants of repayment in the Gramen Bank in Burkina Faso where beneficiaries with multiple sources of loan had low level of defaults and were credit worthier.

Amount of money borrowed contributed positively to loan repayment and significant at $1 \%$ level of confidence. The direct relationship in amount of money borrowed to loan repayment indicated that, as the amount of loan granted to farmers increased, loan amount repaid also increased. This could be explained by the fact that, the more adequate volume of loan is given to a farmer, the more likely that he will make adequate amount available for the farm business which will lead to higher income. This to say that, higher income could be possible with adequate loan volume because of the advantages associated with economies of scale which come about through expansion of purchases and production (Okorji and Mejeha, 1993). This result is in tandem with the findings of Nwosu et al. (2014); Ajah et al. (2013) ; Ajah et al,(2014) ; Afolabi (2010) ; Iqallqbal in reference!, Ahmad and Abbas (2003); Adegbite (2005); Dayanandan and Weldeselassie (2009); Dadson (2012) who established that loan volume disbursed was a significant determinant of loan repayment among farmers.

Total income of the farmers was directly related to the amount of loan repaid and significant at $5 \%$ level of confidence. The direct relationship is in agreement with the expected sign. This indicates that, as the total income of the farmer increased, the loan amount repaid also increased. This is explained by the fact that when total income of the farmer increases, he gets enough money to meet family needs and also meet loan obligations (Okorji and Mejeha, 1993).

\section{CONCLUSION}

Based on the findings from this study, loan repayment performance was low. Loan performance indices estimated show that only $25.94 \%$ of loan collected by farmers were repaid in the period under review. This could place a doubt on the outreach and sustainability capacity of IFS to remain a commercial lending scheme. The causes of this low repayment were mainly diversion of loan and unwillingness to repay loans. Empirical evidence from the multiple regression analysis indicated that sex, loan from other sources, amount of money borrowed and total income were factors that significantly influenced loan repayment in the study area.

From the result of the study, the following recommendations are made. Proper monitoring and supervision on the part of IFS staff should be heightened to ensure prompt repayment. Farmers should be encouraged by the funding agency and also enlightened on the necessity to repay loan. This could be done through education, coaxing and even persuasion and at times necessary threatening such as arrest and exclusion from further funding. The significant variables that influenced loan repayment should be taken into consideration in policy issues because they are fundamental in sustainable financial services to farmers. 


\section{REFERENCES}

Abu, B. M.; Domanban, P. B. and Issahaku, H. (2017). Micro-credit Loan Repayment Default among Small scale Enterprises: A Double Hurdle Approach GJDS, Vol. 14, No 1.

Abu, B. M., Domanban, P. B. and Sekyi, S. (2016). Credit Market Participation by Women-owned small scale enterprises in Wa and Jirapa District of upper West region of Ghana. Ghananian Journal of Economics. Vol. 4. Pp. 71-77.

Acquah. H. D. and Addo, J. (2011) Determinants of loan Repayment Performance of Fishermen: Empirical Evidence from Ghana. CercetariAgronomics Vol.XL1V N0.4 (148).

Adegbite, D. A. (2005).Quantitative Analysis of the Determinants of Loan Repayment under the Nigerian Agricultural Cooperative Bank Small holders Loan Scheme, Ogun State Nigeria. A. 5(1): 1-12

Ajah, E. A., Eyo, E. O. and Abang, S. O (2013). Repayment Performance among Cassava and Yam Farmers under Nigerian Agricultural Bank Small holder Loan Scheme in Cross River State, Nigeria.Brit. J. Econs. Manage. Trade 3(4):453-467.

Ajah, E. A. Eyo, E. O. and Ofem U. I. (2014).Analysis of Creditworthiness and Loan Repayment among Bank of Agriculture Loan Beneficiaries (Poultry farmers) in Cross River State, Nigeria.International Journal of Livestock Production Vol. 5 (9), Pp 115-164

Afolabi, J. A. (2010). Analysis of Loan Repayment Among Small Scale Farmers in Oyo State, Nigeria. J. Soc. Sci. 22(2) 115-119.

ANAN: Association of National Accountants of Nigeria (2017). Options for Financing Agriculture in Nigeria. Jan.-March, 2017 Vol.25 No. 1

Anuku, M. I. and Ebong, V. O. (2011). Analysis of the Performance of Piggery Loan Beneficiaries in the Integrated Farmers Scheme of Akwalbom State: A Case of Uyo Agricultural Zone. Nigerian Journal of Agric. Food and Environment 7(3):73-79.

Aryeety, E. (1995). Financial Integration and Development in Sub-Saharan Africa: A Study of Informal Finance in Ghana: Oversees Development Institute. Working paper No. 78

ARMTI: Agricultural and Rural Management Training Institute (2016). Youth Empowerment Scheme in Agribusiness Training module. December 2016 volume1.

Ayanda, I. F. and Ogunsekan, O. (2012).Farmers' Perception of Repayment of Loans Obtained from Bank of Agriculture, Ogun State, Nigeria J AgriSci, 3(1): 21-27

Dadson, A. V. (2012). Determinants of Loan Repayment Default among Farmers in Ghana.J. Develop. Agric. Econ. 4(13):339-345.

Dayanandan, R and Weldeselassie, H. (2009).Determinants of Loan Repayment Performance among Small farmers in Northern Ethiopia.J. Afr. Develop. Stud. 2:1

Elum, Z. A., Agwuja, V. C. and Ogor, J. U. (2017). Demand for Institutional Credit Among Arable Crop Farmers in Obio-Okpor Local Government Area of Rivers State, Nigeria. Nigerian Journal of Agriculture, Food and Environment 13(2): 99-103. 
Etukumoh, E.A and Akpaeti, A. J. (2015).Analysis of Loan Default and Repayment Performance among Farmers in AkwaIbom State Integrated Farmers' Scheme. RJOAS, 5(41).

Global Agricultural Information Network (GAIN) (2011). Report Paper, Agricultural Finance and Development: the role of land tenure security and public programs. Agricultural Economics 29, 69-84.

Hosseini, S. S., Khaledi, M., Ghorbani, M. and Brewin, D. G. (2012). An Analysis of Transaction costs of obtaining credits in Rural Iran. J. Agr.Sci Tech. 14: 243-256

IqbalIqal in text, M. Ahmad, M. and Abbas, K. (2003).The Impact of Institutional Credit on Agricultural Production.The Pakistan Development Review 42:4 part II, Pp. 469-485.

Mejeha, R.O. and Obunadike, A. (1998).The impact of Credits on Adopting Innovations on Fertilizer Use.Yam Minisett and Cassava in Anambra of Nigeria.Nig. J. Agric.Edu. 1; 4044.

Musugi, M. (2002). Small Farmers and Rural Credit: Struggle for Access. FarmNews 15 (20): 11 16.

Ndiege, B. O; Mataba, L; Msonganzila, M. and Nzilano, K. L. (2016).The link between Financial Performance and Loan Repayment Management in Tanzanian SACCOS.African Journal of Business Management Vol. 10(4) Pp 89-97.

National Planning Commision (NPC) 2006. Community-Based Poverty Reduction Projects (CPRP). Operational Manual, Abuja, Nigeria, Pp 6. NSAP, Calabar $18^{\text {th }}-21^{\text {st }}$ March.

Nwachukwu, I. N., Alamba, C. S. and Oko-Isu, A. (2010).Determinants of institutional credit repayment perfoamance among farmers in Afikpo North LGA of Ebonyi State, Nigeria. $A A B$ Bioflux 2(3): 211-226.

Nwaru, J. C., Essien, U. A. and Onuoha, R. E. (2011). Determinants of informal credit demand and supply among food crop farmers in Akwalbom State, Nigeria. Journal of Rural and Community Development, 6(1):129-139.

Nwosu, F. O; Okorji, E. C; Nweze, N. J; Orebiyi, J. S; Nwachukwu, M. O and Ibekwe, U. C. (2014).Loan Accessibility and Repayment Performance of Livestock Farmers under the Agricultural Credit Guarantee Scheme Fund in Southeast, Nigeria.Developing country Studies Vol.4, No. 6

Okpara, G.C.; Ibeleme, S. N. O. and Odionye, J. C. (2013).Loan Repayment Performance of Small holder Oil Producers in Nigeria: A Credit Rating approach.Journal of Research in Economics and International Finance (JREIF) Vol. 2(5) Pp 88-96.

Okwara, M. O.; Lemchi, J. I.; Ohajianya, D. O and Nwosu, F. O. (2016).Factors Affecting Microfinance Banks Credit Supply to Farmers in Imo State.Developing Country Studies Vol. 6, No5.

Ololade, R.A. and Olagunju, F. I. (2013). Determinants of access to credit among rural farmers in Oyo state, Nigeria. Global Journal of Science Frontier Research Agricultural and Vertinary sciences $13(2), 50-58$. 
Onyenucheya, F. and Ukoha, O.O. (2007). Loan repayment and credit worthiness of farmers under the Nigerian agricultural cooperative rural development bank (NACRDB). Agric. J. 2(2): 265-270.

Okorji, E. C. and Mejeha, R. O. (1993). The formal agricultural loans in Nigeria: the demand for loans and delinquency problems of smallholders' farmers in Owerri. Agricultural Zone of Imo State Nigeria.Int. J. Trop. Agric1:1-13.

Poulton, C., A. Dorward and J. Kydd, (1998). The revival of smallholder cash crops in Africa: public and private roles in the provision of finance, Journal International Development, 10(1):85-103.

Rathore, R.; Mishra, S. and Kumar, P. (2017).Factors Affecting Non-Repayment of Agricultural Loans: A case Study of Rajasthan MarudharaGramin Bank.International Journal of Current Microbiology and Applied Sciences Vol.6 No4 Pp 1052-1059.

Udoh, E. J. (2008). Estimation of loan default among beneficiaries of a state government owned agricultural loan scheme, Nigeria H. Cent. Europ. Agric., 9(2):343-352. 
Table 1: Farmers' responses on the factors that affect loan repayment

\begin{tabular}{llll}
\hline Factors & $\begin{array}{l}\text { Number } \\
\text { Respondents }\end{array}$ & $\begin{array}{l}\text { of } \\
\text { respondents }\end{array}$ & of \\
\hline Delayed loan approval & 59 & 70.23 \\
Incorrect credit appraisal & 20 & 23.81 \\
Diversion of loan to family & 75 & 89.23 \\
Under financing & 18 & 21.43 \\
Poor monitoring & 59 & 70.23 \\
Production losses & 60 & 71.43 \\
Low price of produce & 40 & 47.62 \\
Lack of business knowledge/ & & \\
cost of production & 34 & 40.47 \\
High interest rate charged & 45 & 53.57 \\
Unwillingness to repay loan & 68 & 80.95 \\
\hline
\end{tabular}

Source: Field data, 2017.

Multiple responses recorded

Table 2: Loan statistics of beneficiaries (2011-2015)

\begin{tabular}{|c|c|c|c|c|c|}
\hline \multirow[t]{2}{*}{ Description } & \multicolumn{5}{|l|}{ Enterprises } \\
\hline & $\begin{array}{l}\text { Food crop } \\
\equiv, 000.00\end{array}$ & $\begin{array}{l}\text { Fishery } \\
N, 000.00\end{array}$ & $\begin{array}{l}\text { Piggery } \\
\equiv, 000.00\end{array}$ & $\begin{array}{l}\text { Poultry } \\
\equiv, 000.00\end{array}$ & $\begin{array}{l}\text { Total } \\
¥, 000.00\end{array}$ \\
\hline $\begin{array}{ll}\text { Number } & \text { of } \\
\text { beneficiaries } & \end{array}$ & $\begin{array}{l}45 \\
(53.57)\end{array}$ & $\begin{array}{l}13 \\
(15.48)\end{array}$ & $\begin{array}{l}11 \\
(13.09)\end{array}$ & $\begin{array}{l}15 \\
(17.86)\end{array}$ & $\begin{array}{l}84 \\
(100)\end{array}$ \\
\hline $\begin{array}{l}\text { Amount granted as } \\
\text { loan (\#) }\end{array}$ & $\begin{array}{l}20,250 \\
(50.94)\end{array}$ & $\begin{array}{l}6,500 \\
(16.35)\end{array}$ & $\begin{array}{l}5,500 \\
(13.84)\end{array}$ & $\begin{array}{l}7,500 \\
(18.87)\end{array}$ & $\begin{array}{l}39,750 \\
(100)\end{array}$ \\
\hline $\begin{array}{l}\text { Number of clients } \\
\text { who fully paid }\end{array}$ & $3(6.67)$ & $2(15.38)$ & $1(9.09)$ & $2(20.00)$ & $8(9.52)$ \\
\hline $\begin{array}{l}\text { Amount fully paid } \\
\text { (\#) }\end{array}$ & $\begin{array}{c}1,350 \\
(6.67)\end{array}$ & $\begin{array}{l}1,000 \\
(15.38)\end{array}$ & $\begin{array}{l}500 \\
(9.09)\end{array}$ & $\begin{array}{l}1,000 \\
(13.33)\end{array}$ & $\begin{array}{l}4,350 \\
(10.94)\end{array}$ \\
\hline
\end{tabular}


Volume 16 Number 2, October 2018 pp 75 - 87.

\begin{tabular}{|c|c|c|c|c|c|}
\hline $\begin{array}{l}\text { Those partially } \\
\text { paid }\end{array}$ & $\begin{array}{l}38 \\
(84.44)\end{array}$ & $\begin{array}{l}9 \\
(69.23)\end{array}$ & $\begin{array}{l}9 \\
(81.82)\end{array}$ & $\begin{array}{l}10 \\
(66.67)\end{array}$ & $\begin{array}{l}66 \\
(78.57)\end{array}$ \\
\hline $\begin{array}{l}\text { Amount partially } \\
\text { paid ( }\left(\begin{array}{l} \\
\text { (n) }\end{array}\right.\end{array}$ & $\begin{array}{l}10,400 \\
(51.36)\end{array}$ & $\begin{array}{l}3,750 \\
(57.69)\end{array}$ & $\begin{array}{l}3,420 \\
(62.18)\end{array}$ & $\begin{array}{l}4,000 \\
(53.33)\end{array}$ & $\begin{array}{l}22,060 \\
(55.50)\end{array}$ \\
\hline $\begin{array}{l}\text { Outstanding } \\
\text { amount }(\#)\end{array}$ & $\begin{array}{l}6,700 \\
(33.10)\end{array}$ & $\begin{array}{l}750 \\
(11.54)\end{array}$ & $\begin{array}{l}1,080 \\
(19.64)\end{array}$ & $\begin{array}{l}1,000 \\
(13.33)\end{array}$ & $\begin{array}{l}9,040 \\
(22.74)\end{array}$ \\
\hline $\begin{array}{l}\text { Those who made } \\
\text { no repayment }\end{array}$ & $\begin{array}{l}4 \\
(8.89)\end{array}$ & $\begin{array}{l}2 \\
(15.38)\end{array}$ & $\begin{array}{l}1 \\
(9.09)\end{array}$ & $\begin{array}{l}3 \\
(20.0)\end{array}$ & $\begin{array}{l}10 \\
(11.90)\end{array}$ \\
\hline $\begin{array}{l}\text { Amount not repaid } \\
\text { (N) }\end{array}$ & $\begin{array}{l}1,800 \\
(8.89)\end{array}$ & $\begin{array}{l}1,000 \\
(15.38)\end{array}$ & $\begin{array}{l}500 \\
(9.10)\end{array}$ & $\begin{array}{l}1,500 \\
(20.0)\end{array}$ & $\begin{array}{l}4,300 \\
(10.82)\end{array}$ \\
\hline $\begin{array}{l}\text { Total amount } \\
\text { repaid fully/partial } \\
(\mathrm{N})\end{array}$ & $\begin{array}{l}11,750 \\
(58.02)\end{array}$ & $\begin{array}{l}4,750 \\
(73.08)\end{array}$ & $\begin{array}{l}3,920 \\
(71.27)\end{array}$ & $\begin{array}{l}5,990 \\
(79.87)\end{array}$ & $\begin{array}{c}26,410 \\
(66.44)\end{array}$ \\
\hline $\begin{array}{l}\text { Total amount in } \\
\text { Default( })\end{array}$ & $\begin{array}{l}8,500 \\
(41.98)\end{array}$ & $\begin{array}{l}1,750 \\
(26.92)\end{array}$ & $\begin{array}{l}1,580 \\
(28.73)\end{array}$ & $\begin{array}{l}1,510 \\
(20.13)\end{array}$ & $\begin{array}{l}13,340 \\
(33.56)\end{array}$ \\
\hline
\end{tabular}

Source: Field Survey, 2017.

Figures in bracket are percentages

Table 3: Loan performance of IFS beneficiaries (2011-2015)

\begin{tabular}{lllll}
\hline Enterprise & LRI $(\%)$ & LDI $(\%)$ & BRR $(\%)$ & BDR $(\%)$ \\
\hline Poultry & 11.54 & 88.46 & 63.15 & 36.85 \\
Piggery & 6.82 & 93.18 & 32.67 & 67.33 \\
Fishery & 10.87 & 89.13 & 42.01 & 57.99 \\
Food crop & 74.52 & 25.48 & 9.57 & 90.43 \\
Mean & 25.94 & 74.06 & 36.85 & 63.15 \\
\hline
\end{tabular}

Source: computed from equations 1, 2, 3 and 4

Table 4: Factors that affect loan repayment of IFS beneficiaries

\begin{tabular}{lllll}
\hline Variables & + Linear & Exponential & Semi-Log & Double-Log \\
\hline Intercept & 31836.04 & 12.39532 & -3859412 & 9.986149 \\
& $(0.33)$ & $(71.85)^{* * *}$ & $(-4.35)^{* * *}$ & $(10.07)^{* * * *}$ \\
Sex & 79647.37 & -.2245468 & -32662.64 & -.1796732 \\
& $(2.72)^{* *}$ & $(-2.22)^{*}$ & $(0.30)$ & $(2.49)^{*}$ \\
Age & -715.1137 & -0037058 & 39696.5 & .1493249 \\
& $(-0.46)$ & $(1.34)$ & $(0.39)$ & $(1.33)$ \\
Farm type & -18536.44 & .0363605 & -139713.3 & -.0845341 \\
& $(0.50)$ & $(0.45)$ & $(-1.46)$ & $(-0.79)$
\end{tabular}

Journal of the Faculty of Agriculture and Veterinary Medicine, Imo State University Owerri website: www ajol.info 

Volume 16 Number 2, October 2018 pp 75 - 87.

\begin{tabular}{lllll}
\hline Education & -601.5176 & .0077302 & 54825.94 & .0041455 \\
& $(-0.17)$ & $(1.01)$ & $(0.70)$ & $(0.05)$ \\
Loan from other & 46288.65 & .0389289 & 174012.5 & .1386284 \\
sources & $(2.66)^{* *}$ & $(0.42)$ & $(1.60)$ & $(2.14)^{*}$ \\
Farming Experience & $1 \mathrm{v} 904.5$ & -.0025389 & 131706.9 & .553196 \\
& $(1.32)$ & $(-0.65)$ & $(0.97)$ & $(1.03)$ \\
Amt. borrowed & .7830635 & 5.3907 & 97451.18 & .0368182 \\
& $(19.11)^{* * *}$ & $(6.15)^{* * *}$ & $(2.38)^{*}$ & $(0.81)$ \\
Total income & 81166.56 & -0.0176743 & -272.3879 & -.0053224 \\
& $(2.93)^{* *}$ & $(0.18)$ & $(0.02)$ & $(0.32)$ \\
Interest amount & 28.70123 & -.0000301 & 326453 & .1848005 \\
& $(1.62)$ & $(0.80)$ & $(4.35)^{* * *}$ & $(2.15)^{*}$ \\
$\mathrm{R}^{2}$ & 0.8581 & 0.3903 & 0.3214 & 0.3580 \\
F-ratio & 49.73 & 5.26 & 0.0007 & 0.1719 \\
\hline
\end{tabular}

Source: Data Analysis 2017: Figures in brackets are t-values. $* * *, * *, *=$ significant at $1 \%, 5 \%$ and $10 \% ;+=$ the lead equation. 